\title{
The Correlation between Physical Workload and the Increase in Workers' Pulse Rate
}

\author{
Hubungan antara Beban Kerja Fisik dengan Peningkatan Denyut Nadi \\ Pekerja
}

\author{
Elsya Vira Putri \\ THIESS level 5, 179 Grey Steet \\ South Bank, Queensland, Australia 4101
}

\begin{abstract}
Introduction: The workload that exceeds individual work capacity will increase the pulse rate rapidly. The purpose of this research was to study the correlation between physical workload and the increase in workers' pulse rate. Methods: This research utilized cross-sectional design by using the observational method with 23 workers from the BRF area of PT X Sidoarjo as respondents. This research was conducted by conducting the direct observation by calculating the workload received by the worker by using \%CVL method and calculating the resting and working heart rates. Results: The result showed that all workers were male and had the productive age distribution of $60.9 \%$ in the age range of $25-50$ years. Based on the calculation of workload, the majority of workers have the workload on the moderate \%CVL category, amounting to 56.5\%. Based on the measurement of the resting and working heart rates, it was found that all workers experienced the pulse rate increase. Based on the result of Pearson correlation statistical test, the result was $\mathrm{p}<0.05$, which means that there was a significant correlation between the workload and the increase in the workers' pulse rate. Moreover, the correlation coefficient was 0.911 , that indicated a very strong and positive correlation. Conclusion: This research concludes that there is a strong and positive correlation between workload and the increase in the workers' pulse rate.
\end{abstract}

Keywords: \%CVL, cardiovascular load, workload, pulse rate

\section{ABSTRAK}

Pendahuluan: Beban kerja yang melebihi kapasitas kerja akan menyebabkan peningkatan denyut nadi secara cepat. Penelitian ini dilakukan untuk mempelajari hubungan antara beban kerja fisik dengan peningkatan denyut nadi pekerja. Metode: Penelitian ini menggunakan desain penelitian cross sectional dengan metode observasional. Responden dalam penelitian ini sebanyak 23 pekerja di Area BRF PT X Sidoarjo. Penelitian ini dilakukan dengan melakukan observasi langsung dengan cara menghitung beban kerja dari pekerja menggunakan metode \%CVL dan menghitung denyut nadi istirahat dan denyut nadi kerja. Hasil: Penelitian menunjukkan bahwa seluruh pekerja berjenis kelamin laki-laki dan memiliki distribusi usia produktif yaitu sebanyak 60,9\% pada range usia 25-50 tahun. Berdasarkan perhitungan beban kerja pada pekerja mayoritas memiliki beban kerja pada kategori \% CVL sedang yaitu sebanyak 56,5\%. Berdasarkan pengukuran denyut nadi istirahat dan denyut nadi kerja didapatkan hasil bahwa seluruh pekerja mengalami peningkatan denyut nadi. Berdasarkan hasil uji statistik kolerasi person didapatkan p<0,05 yang artinya terdapat hubungan yang signifikan antara beban kerja dengan peningkatan denyut nadi pekerja serta didapatkan koefisien kolerasi 0,911 yang menandakan adanya hubungan yang sangat kuat dan bersifat searah. Simpulan: Semakin tinggi beban kerja yang diterima oleh pekerja maka semakin cepat peningkatan denyut nadi pada pekerja.

Kata kunci: \%CVL, beban kardiovaskuler,beban kerja, denyut nadi

Corresponding Author:

Elsya Vira Putri

Email: viraputri610@gmail.com 


\section{INTRODUCTION}

The rapid development of technology generates a rather great impact, particularly in the industry sector. The higher the consumer needs, the greater the impact in the form of production increase in a company, which will impact the labor as well. The increase in the production process renders the demands to the labor to work harder to meet the daily target set by the company.

Various kinds of industry start to develop, along with technology development. This situation causes several companies to use more sophisticated machines. The use of technology is closely related to the humans operating it. The increasing consumer needs also force the company production to be able to fulfill the needs. The workload received by the labor or the workers becomes greater to meet the daily production target.

Every work has a different workload depending on the types and duration of the work. In terms of ergonomics, any workload received by an individual must be balanced with the physical capability of the worker himself (Tarwaka, 2015). The workers are enforced to follow the rotating work system or shift that also increases the workload received by them. The different work environment among companies also generates a different workload.

The research at PT Indo Acidatama, Tbk in 2010 stated that the labor working in the mechanical division experienced the pulse rate increase, which brought the weight for more than $40 \mathrm{~kg}$. The analysis of the pulse rate increase is interpreted such way due to the workload received by the labor is not included in the light category. From the result of the study, it can be observed that there was the influence of the workload received by the labor to their pulse rate increase (Mei, 2010).

There are many companies orienting to the results that can be obtained daily by the companies, yet they pay less attention to the workload received by the workers. The workload received by the workers can be divided into physical and psychological workloads. Both kinds of workload deteriorate the workers' health if the workload received by the workers is not in accordance with the capacity owned by the workers.

The physical work is any activity that requires physical capability on the human muscle that functions as the power source. The physical work is usually known as the manual operation, in which the labor becomes the main control of the work, so the work performance fully relies on the labor's efforts (Tarwaka, 2015).

Pulse is the most effective method in measuring the workload index. The pulse rate measurement conducted when the workers do their work is a method to measure someone's cardiovascular strain. When the heart works hard in pumping blood throughout the body, it will affect the cardiovascular load (Lestya, Rachman and Wiediartini, 2016).

The workload analysis becomes an important role in the optimization effort of human resource in the companies. Observed from the ergonomic standpoint, there needs to be a balance between the task demands and working capacity so that the high working productivity can be achieved. The workload that is too high and too low can stress the workers (Rizqiansyah, Hanurawan and Setiyowati, 2017).

According to Santoso (2004), the workload difference received with the capacity owned by an individual can cause different issues. If the workload condition received by the workers is greater than the capacity owned by them, the workers can feel several things like inconvenience (initial stage), fatigue (overstress), injury, accident, pain, disease, and reduced productivity (final stage). If the workload received by the workers is less than their capacity, the workers will experience under stress, flatness, boredom, and less productiveness (Fahamsyah, 2017).

The weight of the physical workload received by the workers will determine how long the workers can do the work in accordance with the capacity owned by them before feeling exhausted (Stariszky, Ekawati and Jayanti, 2016). According to Nurmianto (2004), the increase in physical workload to the workers in doing their job will be balanced with the increase in oxygen consumption. After that, the exhaustion will emerge when the oxygen consumption reaches the maximum point and decreases, which will be manifested in the increase in lactic acid (Maharja, 2015).

PT $X$ Sidoarjo is a manufacturing company which operates in the steel smelting. The main material utilized in the production process is steel scrap. The BRF Area is one of the production division of the billet heating process. At the BRF area and the types of work are divided 
into three types. The operator operates the burner machine; the quality control controls the billets before and after heating, and deburring does the heavier physical duty of cleaning the residue piled up under the burner machine from the burner division. This residue is to be transported to the B3 waste disposal.

The activities of the deburring workers are shoveling residue under the burner, lifting the bucket, containing residue $( \pm 25 \mathrm{~kg} / \mathrm{bucket})$, pushing the wagon containing residue, and linking the chain from the bucket containing residue to the pulley. Besides the physical workload, there is another environmental factor, such as the hot work climate. The workers at the BRF area should be exposed to heat from the burner machine for the billet heater. The hot work climate will affect the increase in the workers' body temperature and pulse rate (Hendra, 2003).

According to Grandjean (1993), the calculation method of energy consumption is not sufficient in estimating the physical workload. The physical workload is not only determined from the number of calories consumed, but also from the number of muscles involved and the static load received, so the pulse rate increase can be utilized as the reference to discover the individual's workload (Tarwaka, 2015).

The work environment also becomes one of the relatively influential factors to someone's physical capability. The less conducive work environment such as the hot work climate can affect the discharge of body liquid in the form of sweat that later will affect the workers' health like dehydration.

This research aims at observing the correlation strength between the workload and pulse rate increase of the workers at the BRF area of PT X Sidoarjo.

\section{METHODS}

This research was conducted at the BRF area of PT X Sidoarjo, which is the production division of steel smelting. The research was conducted in February-March 2018.

This research was the observational research since this research did not give any treatment yet only conducted the observation. The research design was the cross-sectional since the observation for each variable was conducted at the same time.
The population of this research was all workers at the BRF area of PT X Sidoarjo with three types of work, that is operator, quality control, and deburring, which is as many as 23 workers. The sample of this research is the total population of 23 workers.

This research employed two variables, that is the dependent and independent variables. The independent variables were age, sex, working period, and workload. Meanwhile, the dependent variable was the workers' pulse rate increase.

The data used in this research were the primary and secondary data. The primary data was taken from the direct observation technique by using a questionnaire as the data instrument to collect the respondent data regarding age, sex, and working period. The workload measurement sheet utilized \%CVL method while the workers' pulse rate increase was calculated by comparing the respondents' resting and working heart rates.

The secondary data were obtained from the archive data of the related company. The collected data will be analyzed using the Pearson correlation statistical test with a significance level $(\alpha)$ of $5 \%$.

\section{RESULTS}

\section{Characteristics of Respondents}

From the observation in the production area of BRF of PT X, it was found that the distribution result of respondent characteristics varied. The respondent characteristics include the workers' age, sex, working period, and type of work. The frequency distribution of respondent characteristics is presented in Table 1.

Table 1. The Frequency Distribution of Respondent Characteristics at PT. X 2018

\begin{tabular}{lcc}
\hline \multicolumn{1}{c}{ Respondent Characteristics } & N & \% \\
\hline Age & 9 & 39.1 \\
< 25 years & 14 & 60.9 \\
25-50 years & & \\
\hline Sex & 23 & 100 \\
Male & & \\
\hline Working Period & 5 & 21.7 \\
< 5 years & 9 & 39.1 \\
5-10 years & 9 & 39.1 \\
\hline 10 years & & \\
Type of Work & 14 & 61 \\
Deburring & 6 & 26 \\
Operator & 3 & 13 \\
Quality Control & & \\
\hline
\end{tabular}


From the research result, the youngest respondent was 22 years old, and the oldest was 50 years old. From Table 1, it can be seen that most of the workers at the BRF area of PT X were in the age range of 25-50 years, amounting to 14 workers $(60.9 \%)$ from the total workers' population. In Table 1, it is also identified that all workers in the BRF area of PT X Sidoarjo were male.

Meanwhile, the respondents' frequency distribution based on the working period is also found in Table 1 , in that the majority of the workers at the BRF area of PT X Sidoarjo had 5-10 years working period, amounting to nine workers $(31.9 \%)$, and more than ten years with the exact same percentage.

The respondent frequency distribution based on their types of work at the BRF area of PT X Sidoarjo can also be discovered in Table 1 , in which the majority of workers at the BRF area of PT X Sidoarjo worked in the deburring division, amounting to 14 workers $(61 \%)$.

\section{Workload}

The workload was calculated by using the \%CVL method, that is the physical workload calculation observed from the cardiovascular load.

The physical workload calculation by using \%CVL method was obtained from the calculation result of the working pulse, which became the difference between the resting and working heart rates compared to the maximum pulse. Therefore, the \%CVL method can be formulated as follows:

$$
\% C V L=\frac{100 x(W H R-R H R)}{\operatorname{Max} H R-R H R}
$$

Information:

WHR = working heart rate

RHR $=$ resting heart rate

Max HR = maximum heart rate (220-age)

Table 2. The Calculation Result of Respondents' Physical Workload with \%CVL Method at PT. X 2018

\begin{tabular}{ccc}
\hline Type of Work & $\begin{array}{c}\text { \%CVL } \\
\text { Average }\end{array}$ & Workload Category \\
\hline Deburring & $61.3 \%$ & Rather Heavy \\
Operator & $52.76 \%$ & Moderate \\
Quality control & $56.1 \%$ & Moderate \\
\hline
\end{tabular}

The result of workload calculation in Table 3 indicates that the majority of workers at the BRF area of PT X has the \%CVL category result of Moderate, which is as many as 13 respondents (56.5\%). Therefore, it can be interpreted that as many as 13 respondents receive moderate workload $(30-<60 \% \mathrm{CVL})$. The result also demonstrates that the majority of workers who received the workload were from the deburring division.

Table 3. The Frequency Distribution of Respondents' Physical Workload at PT. X 2018

\begin{tabular}{lcc}
\hline \% CVL Category & n & \% \\
\hline Moderate & 13 & 56.5 \\
Rather Heavy & 10 & 43.5 \\
\hline Total & 23 & 100 \\
\hline
\end{tabular}

\section{Pulse Rate}

The pulse rate measurement of the workers at the BRF area of PT X Sidoarjo was taken before the workers start working and during the work. The state before they work is called the resting heart rate where the workers' pulse does not receive workload. The pulse rate measurement when the workers work is called the working heart rate where the pulse receives workload. It was intended to show the workers' pulse rate increase.

Table 4. The Frequency Distribution of Workers' Pulse Rate Increase at PT. X 2018

\begin{tabular}{lcc}
\hline \multicolumn{1}{c}{ Workers' Pulse Rate Increase } & n & \% \\
\hline Increasing & 23 & 100 \\
\hline Total & 23 & 100 \\
\hline
\end{tabular}

From Table 4, it can be seen that the workers' pulse rate before receiving the workload is lower than after receiving the workload. Based on Table 1, it can be seen that all workers in the BRF area were male.

\section{Correlation between the Physical Workload and the Workers' Pulse Rate Increase at the BRF Area of PT X}

The result of Pearson correlation statistical test shows that the correlation between the physical workload and pulse rate increase of workers at the BRF area of PT X has the value of sig. (2-tailed) <0.05. Thus, it can be concluded that there is a significant correlation between the 
physical workload received by the workers and their pulse rate increase. From Table 6, it can also be discovered that the value of the Pearson correlation reached 0.911 . It can be said that the correlation strength between the two variables was extremely strong and positive. It means that the heavier someone's workload was, the faster his pulse rate increased.

\section{DISCUSSION}

\section{Age}

The workers' age is the age calculated from the day he was born to the day of observation. The age group obtained in the research at the BRF area of PT X mostly came from the age range of 25-50 years. This age group was categorized as young adult and productive group. The workers at the BRF followed the shift system for their working hour where the youngest worker was 22 years old while the oldest was 50 years old.

According to the Schwartzenau theory proposed by Granjean, there are several factors that need to be concerned, and one of them is age. The good age range for shift workers is more than 25 to 50 years old. Meanwhile, at PT $\mathrm{X}$, there were still shift workers under 25 and above 50 years old (Nurmianto, 2004).

Someone's age is beneficial to determine his physical capability. It is in line with the research conducted by Ambarwati (2014) which stated that the older someone is, the lower his physical capability. Moreover, the older he gets, the lower his immune system, which makes him more susceptible to the physical diseases that will reduce his capability to receive workload.

At the BRF area of PT X, it can be seen that the company prioritizes the young adult workers who were still productive with the consideration that they had the better physical capacity to receive the heavier physical workload. At the deburring division, the youngest worker was 22 years old while the oldest was33 years old.

Age also determines the pulse frequency. According to Sandi (2016), every age has a different pulse frequency. The people of 21-28 years have the average pulse frequency of 73 beats/minute, and it will decrease the older they get. The average resting heart rate of adults is 60-80 beats/minute.

\section{Sexes}

The BRF area of PT X employed 23 workers. All workers in the area were male. The company considered the issue since the production process, particularly at the BRF area of PT X, has the physical work demands that are relatively heavy.

Someone's sex is also related to his physical capability. The male workers have greater muscle mass so they can perform a lot more physical work than female.

In addition to considering the physical workload received by the workers, the working hour is also considered. The workers at the BRF area of PT X. did the work in the shift system so that this area prioritizes male workers instead of female.

Sex is also related to the individual's pulse. According to Sandi (2016), female individuals have a higher pulse frequency than male. At the age of 21-28 years, the male has the average pulse frequency of 73 beats per minute while the female at the same age range has a higher average, that is 80 beats/minute. Besides, at the older ages of 70-77 years, the male has the average resting heart rate of 67 beats per minute while the female has a higher average, reaching 81 beats per minute.

\section{Working Period}

Working period is the period in which someone shows his involvement and loyalty to an organization or company he works with (Setyaningsih, 2007). The longer working period shows that someone's experience and loyalty to the company his works with are quite high.

From the data obtained from the observation result, it is found that the workers at the BRF area of PT X have mostly worked for five to more than ten years. Someone's working period determines his ability to adapt to his work environment, particularly in the physical and psychological work environment. The BRF area of PT X has the work environment with a hot climate, considering that the billet heating process before being formed into the wire rood happens in this area, and the workers of deburring division are directly exposed to the heat from the burner machine. The workers' working period correlates with the ability of his body condition to adjust itself with the hot work environment.

Moreover, someone's working period is also related to the adjustment to the work system, 
organization culture, and leadership in the company. Therefore, someone who has a longer working period will understand the organization condition and work system in the company easier.

\section{Types of Work}

The types of work in the BRF area of PT $\mathrm{X}$ were diverse and had different levels of difficulty and accuracy. At the BRF area of PT $\mathrm{X}$, there was the billet heating process in which the billets that were still in the form of beams were heated on the burner machine to ease the billet formation into the wire rod. In the process, there were three types of work, i.e., operator to operate the billet heating process with the burner,; quality control to check the billet quality before and after heating; and deburring to be done at the area near the burner.

The various types of work indeed had different physical workload. The deburring workers had the work which tended to use a greater physical power compared to the operator and quality control workers. Moreover, the operator and quality control workers mostly worked in the control room so that they were not directly exposed to the heat from the burner machine. The deburring workers worked in the area near the burner machine so that they were directly exposed to the heat from the burner machine.

The deburring workers were the ones cleaning the mill scale, which was the residue of the burner machine. The residue of the burner machine was collected manually using shovels to be poured into the bucket for about $25 \mathrm{~kg} /$ bucket and was brought to the B3 waste disposal by using a pulley. From the work description, it can be seen that the workers of the deburring division had greater physical work demands.

\section{Workload}

In every work, the workers will receive the workload from outside their body Atiqoh, Wahyuni and Lestyanto (2014). The physical workload is the demands achieved from the physical activities of work. The workload of every individual is different. The workload difference among individuals is influenced by the variety of individuals' characteristics and physical capabilities. According Tarwaka (2015), the physical workload is related to the muscle work and physiological function of the body.

From the observation result of workload measurement at the BRF area of PT X, it can be seen that the majority of the deburring workers received a rather heavy workload from the work they did, and it required improvement. It was obtained from the workload calculation result with a \%CVL method that the majority of the deburring workers was included in the \%CVL category of rather heavy, that was in the range from $60 \%$ to less than $80 \%$.

Based on the obtained data from the observation result, most of the deburring workers received a rather heavy workload, while the majority of operator and quality control workers received a moderate workload. It occurs because, in the deburring division, the workers receive the additional workload from the work environment, that is the hot work climate. This research does not focus deeper on the work climate.

According to Purwaningsih and Aisyah (2016), the work environment which has hot work climate will give the additional load to the workers' body. It occurs because if the heat enters the body, the body will respond in discharging the excessive heat from the body so that the body organs will work way harder to give off the excessive heat. The deburring workers had a greater workload compared to the operator and quality control workers who were not directly exposed to the heat from the burner machine.

Besides, the work in the BRF area of PT X was still handled manually, especially by the deburring workers who were found to work manually. The workers in this division had a greater average workload, and a higher pulse rate increase.

\section{Pulse Rate Increase}

Pulse is the result of blood pumping by the heart to the blood vessel Sandi (2016). The role of a pulse rate increase in workers is significant in determining the cardiac output increase, starting from the resting position or when the workers do not receive the workload to the point where they receive the workload from the maximum work. It happens due to the strong correlation between pulse and oxygen intake when working (Tarwaka, 2015).

Based on the observation result of pulse rate measurement on the BRF area workers at PT $\mathrm{X}$, all workers experience the pulse rate increase. 
The workload and hot working climate cause a rapid pulse rate increase (Rahadian, 2016).

The pulse rate measurement was conducted in two conditions that were the resting heart rate and working heart rate. The resting heart rate is the pulse taken before the workers do their job and do not receive workload from any working activity. Meanwhile, the working heart rate is the pulse when the workers receive workload from any working physical activity.

The workers' pulse rate increase was obtained from the different results of their resting and working heart rates. ACGIH recommends that the limit of working heart rate should not exceed 180 - workers' age pulse per minute. The observation result of the working heart rate measurement at the BRF area of PT $\mathrm{X}$ indicated that all respondents acquire the working heart rate that is still below the NAB set by ACGIH.

However, the pulse rate increase of the $\mathrm{BRF}$ area workers at PT $\mathrm{X}$ is not in line with the research conducted by Moeljosoedarma (2008), which claims that the increase of the workers' pulse rate in the hot work climate and heavy workload is approximately $20-40$ beats/minute. This occurs due to the various characteristics of the individuals, such as age, sex, working period, type of work, and history of physical illness owned by the workers.

\section{Correlation between the Workload and the Workers' Pulse Rate Increase at the BRF Area of PT X}

The pulse rate increase of the workers at the BRF area of PT X Sidoarjo occurs due to the physical works and hot environment so that it causes static muscle fatigue (Mei, 2010).

To the workers who undergo the workload beyond their capacity, they will experience fatigue. It is caused by the accelerated process in the pulse rate increase so that the body responds to the condition with fatigue as the sign to take some rest.

Based on the observation result, the data of physical workload and pulse rate measurement of the workers at the BRF area of PT X were obtained. The data was then tested statistically to discover the strong correlation between the physical workload received by the respondents and their pulse rate increase. The utilized correlation strength test is the Pearson correlation statistical test. From the correlation test, the significance value (2-tailed) reached less than 0.05 , which indicates an extremely strong correlation between the workload and the pulse rate increase of the BRF area workers at PT X.

This research is in line with the one conducted by Purwaningsih and Aisyah (2016) which focused on three factors that could affect the increase of the pulse rate, that is climate, body weight, and workload. The result was that the workload acquired a greater influence than climate and body weight.

Similar research was conducted by Yoopat, Toicharoen, Glinsukon, Vanwonterghem, and Louhevaara (2002) to the construction workers in Thailand who worked outdoor and were exposed to the direct solar heat. The results of the research indicate that the workload contributed to the higher influence in the increase of the workers' pulse rate instead of the heat pressure of the work environment produced by the direct sun exposure. It was caused by the work which required greater muscle strength.

According to Tarwaka (2015) the sensitivity level of the pulse rate toward the change in the workload received by the body is extremely high. Therefore, when someone's body receives the workload from the work he does, it will be followed by the increase in his pulse rate. The higher the received workload, the increase in the pulse rate is relatively faster. According to Kurniawan (1995), the pulse rate will change in accordance with the received workload.

An increase in the pulse that is too fast can trigger a person to experience fatigue. It can be resolved by stretching taking enough rest. Moreover, considering that there are still many kinds of works handled manually, redesigning the work equipment can be performed by utilizing the auxiliary tools to alleviate the physical workload, specifically in the deburring division. Consuming as much water as possible is also suggested since the BRF area is the section of billet installation that the hot environment causes the workers to be susceptible to dehydration.

The hot environment triggers the discharge of excessive body fluids, which causes the body to dehydrate. If it is not resolved immediately, it can render several health effects like heat stroke. Therefore, the company is expected to make an appeal to the workers for maximizing their time in taking some rest and consuming water to 
maintain the fluid level in their body (Tasyrifah, 2017).

\section{CONCLUSION}

Based on the research results, the BRF area of PT X Sidoarjo has workers with the characteristics of the male, mostly in the productive age with the age range of 25-50 years, the working period is mostly over five years, and the division with the most workers is the deburring division. All workers who undergo physical workload experience an increase in their pulse rates.

The works that are still handled manually have a huge influence on the workload received by the workers. The hot environment can also affect the workload, which also influences the escalation in the workers' pulse rates.

The workload received by the workers in the BRF area of PT X Sidoarjo is related to the increase of the workers' pulse rates. The correlation between the two variables is directly proportional since the higher the received workload, the faster the increase of workers' pulse rate.

\section{ACKNOWLEDGMENT}

The researcher would like to express her utmost gratitude to God Almighty, research advisor, as well as the respondents and PT X for participating in this research.

\section{REFERENCES}

Ambarwati, F. R. (2014) The Concept of Basic Human Needs. Yogyakarta: Parama Ilmu.

Atiqoh, J., Wahyuni, I. and Lestyanto, D. (2014) 'Factors Associated with Work Fatigue in Workers Convection Section Tailoring at CV. Aneka Garment Gunungpati Semarang', Jurnal Kesehatan Masyarakat FKM Undip, 2(2), pp. 119-126.

Fahamsyah, D. (2017) 'Analysis of Relationship between Mental Workload and Job Stress', The Indonesian Journal of Occupational Safety and Health, 6(1), pp. 107-115.

Grandjean, E. (1993) Fitting the Task to the Man. 4th edn. London: Taylor \& Francis Inc.

Hendra (2003) Factors That Affect the
Increasing of Body Core Temperature and Heart Rate on Workers Exposed by Heat (Case Study at Cor Department, Tempa and Cor Division, PT Pindad (Persero), Bandung 2003). Thesis. Depok: Master in Public Health Sciences, Universitas Indonesia.

Kurniawan, D. (1995) 'Significance of the Working Pulse as a Parameter for Loading', Majalah Hiperkes dan Keselamatan Kerja XXVIII (2), pp. 20-25.

Lestya, D. W. N., Rachman, F. and Wiediartini (2016) 'Analysis of External and Internal Factors Affecting Physical Workloads on Finishing Work in Steel Fabrication Companies', in Proceeding 1st Conference on Safety Engineering and Its Application, pp. 24-28.

Maharja, R. (2015) 'Analsys of Level of Work Fatigue based on Physical Workload of the Nurses in Inpatient Care Unit of RSU Haji Surabaya', The Indonesian Journal of Occupational Safety and Health, 4(1), pp. 93-102.

Mei, E. D. (2010) Effect of Work on Charges in Labor Pulse Mechanical Part in PT. Indo Acidatama, Tbk. Kemiri, Kebakkramat, Karanganyar. Undergraduate Thesis. Surakarta: Facuty of Medicine, Universitas Sebelas Maret.

Moeljosoedarma, S. (2008) Higiene Industri. Jakatra: Faculty of Medicine, Universitas Indonesia.

Nurmianto, E. (2004) Ergonomics: Basic Concepts and Applications. Surabaya: Guna Widya.

Purwaningsih, R. and Aisyah (2016) 'Analysis the Effect of Temperatur, Body Weights, and Work Load to Heart Pulse Level of Airport Ground Handling Worker', Jurnal Teknik Industri, 11(1), pp. 15-20.

Rahadian, R. R. (2016) The Relationship between Heat Pressure and Workload with Increasing the Pulse Rate of Workers in the BRF and TFH Work Areas at PT. X. Undergraduate Thesis. Surabaya: Faculty of Public Health Universitas Airalngga.

Rizqiansyah, M. Z. A., Hanurawan, F. and Setiyowati, N. (2017) 'Relationship between Physical Workload and Ergonomics-Based Mental Workload Against Work Saturation Levels at Employees of PT Jasa Marga (Persero) Tbk Surabaya Branch Gempol', Jurnal Sains Psikologi, 6(1), pp. 37-42. 
Sandi, I. N. (2016) 'Effect of Physical Exercise on The Pulse Rate', Sport and Fitness Journal, 4(2), pp. 1-6.

Santoso, G. (2004) Safety Management and Occupational Health. Jakarta: Prestasi Pustaka.

Setyaningsih, L. (2007) Work Stress on Teacher Viewed from the Social Support and Work Period. Undergraduate Thesisi. Semarang: Faculty of Psychology Universitas Katolik Soegijapranata.

Stariszky, O., Ekawati and Jayanti, S. (2016) 'The Correlation between Work Load and Work Climate with Fatigue in Land Surveying Job using Theodolite.', Jurnal Kesehatan Masyarakat FKM Undip, 4(3), pp. 549-556.

Tarwaka (2015) Industrial Ergonomics: Basics of Ergonomics Knowledge and Applications at Work. 2nd edn. Surakarta: Harapan Press.

Tasyrifah, G. M. (2017) The Difference Level of Dehydration and Fatigue on Exposure Labor by Hot Working Climate at PT. Panen Boyolali. Undergraduate Thesis. Surakarta: Faculty of Health Science, Universitas Muhammadiyah Surakarta.

Yoopat, P., Toicharoen, P., Glinsukon, T., Vanwonterghem, K., Louhevaara, V. (2002) 'Ergonomics in practice: Physical workload and heat stress in thailand', International Journal of Occupational Safety and Ergonomics, 8(1), pp. 83-93. 